\title{
The Essential Role of Play in School Contexts for the Well-Being of Children
}

Sandra J. Stone

\begin{abstract}
This article affirms the essential role of play for the well-being of children within the school context. The article explores the definition of play, why play is so important, gives examples of play in schools, and advocates for a child-centered approach to learning. The downside of a curriculum-centered approach is explored as an agent of anti-well-being for children. Standards and standardized tests are toxic to children's healthy growth and development, crowding out or eliminating play from schools. The article advocates for a place for play in schools in order to promote the well-being of every child.
\end{abstract}

\section{The Essential Role of Play in School Contexts for the Well-Being of Children}

Play is essential for all children. It is not just important, a good thing to provide for children, an enjoyable experience for children-It is LIFE ESSENTIAL for children! A NECESSITY for the well-being of children!

In the 1800s, John Dewey, the father of progressive education in the United States, criticized the factory model approach to education, which controlled schooling in the 19th century. Schools became the instrument for preparing children to fit into an industrialized society (Stone, 2004). Dewey (1938) described this approach as "mechanical," with uniform curriculum and methods. He was genuinely concerned about the "well-being of children" who became "products" on the conveyor belt of education, instead of unique and valued individuals. Now in the 21 st century, some types of schooling are still manipulating children as products instead of individuals; schooling, for some, is not about children learning and meeting the needs of the whole child, but it is narrowed to prescribed "standards" in a corporate modeling of education with expressed goals that do not include the "well-being" of children. The impact of standards-based education and the accompanying benchmarks of approved learning and standardized, high-stakes testing, polarizes some education models into a frigid zone which does not allow children to thrive as learners and human beings, and certainly does not value the well-being of the child in the school context. Miller and Almon (2011) agree that this approach with its "uniformity and mechanistic perfection" is inappropriate and that a "mechanical view of the human being cannot succeed" (p. 3).

Diane Ravitch (2010) states that, "schools will surely be failures if students graduate knowing how to choose the right option from four bubbles on a multiple-choice test, but unprepared to lead fulfilling lives ..." (p. 224). She begs the question as to what do we want for our children when we send them to school? Do we want them to think of schooling as places of "drudgery, worksheets, test preparation, and test taking?" (p. 231). Educators and physicians are concerned about increasing the stress children are 
experiencing in schools and agree that the "outcomes of this hurried curriculum are unhealthy" (Miller \& Almon, 2011, p. 1).

Gray (2011) sees a sharp decline of play in the past 50 years and conversely, a sharp rise of psychopathology in children. As play, especially outdoor play, has declined, "anxiety, depression, feelings of helplessness, and narcissism" (p. 443) have increased. Gray argues that without play, children "fail to acquire the social and emotional skills necessary for healthy psychological development" (p. 444). Gray agrees that one of the causes of a decline in children's play is the change in schools to more adult-directed academics and less recess time or none at all. He is concerned that the decline in play is directly related to a "decline in children's mental health" (p. 453). Indoor, outdoor, and nature play all support children's overall well-being (Dowdell, Gray, \& Malone, 2011), yet play is being pushed out of our schools in favor of teacher-led, curriculum-centered approaches (Almon, 2013).

The questions to consider are: Do we want more from our schools? More importantly, do we want more for our children from schools? Do we want places where children can flourish, to be healthy and grow well? Is our children's well-being important to us? Do we want them to be happy, secure, safe, and cared for? Do we want them to experience the joy of learning and the fulfilment of life? Are we willing to sacrifice our children's well-being for arbitrarily determined academic success defined by test scores? Unfortunately, many schools are cutting back on children's play, or eliminating it all together in order to boost test scores (Chmelynski, 2006; Graue, 2010; Levin, 2012; Neason, 2015). Strong affirmation of the essential role of play in the school context for the well-being of children is imperative.

\section{Play and Well-Being}

As educators, the underlying foundation for schooling should be the utmost care for children and their well-being. The well-being of children means that the child is healthy, well, whole in his or her entire being-physically, socially, emotionally, and cognitively, not just an absence of disease (Humberstone, 2009). The Association for Childhood Education International (ACEI) embraces the role of play in children's lives and their sense of well-being. ACEI "believes that play - a dynamic, active, and constructive behavior - is an essential and integral part of all children's healthy growth, development, and learning across all ages, domains and cultures" (Isenberg \& Quisenberry, 2002, p. 33). Research (Burriss \& Tsao, 2002; Carlsson-Paige, 2008; Copple \& Bredekamp, 2009; Dickey, Castle, \& Pryor, 2016; Elkind, 2007; Fiorelli \& Russ, 2012) supports the relationship of play to life's satisfaction and the role of play for children's overall well-being. Play is recognized as an indispensable element in child development and a critical ingredient in a child's education (Frost, 1992). The National Association for the Education of Young Children (NAEYC) supports play as essential for developmentally appropriate practices in schools (Copple \& Bredekamp, 2009). The Alliance for Children expresses concern for the decline in children's health and well-being and the endangerment of childhood itself (Miller \& Almon, 2009). So, if play is essential to children's "well-being," then it demands our attention and our advocacy to provide for play within the school context. We cannot rob our children of this "valuable resource for optimal growth and learning" (Carlsson-Page, 2008, p. 44). We cannot trade our substantive research 
about children and learning for an approach that is not grounded in the principles of child development (Jachyra \& Fusco, 2016; Miller \& Almon, 2011).

\section{Definition of Play}

Children's play can be misunderstood, particularly play in the school context. Active learning may be labeled "play" when actually it is teacher-directed active learning-which is good-but it is not play. Play (Johnson, Christie, \& Wardle, 2005; Stone, 1993, 1995) is defined as intrinsically motivated where children pursue play for their own satisfaction, learning, and needs. Something or someone is not leading, guiding, or directing the play experience. Choice is another attribute of play where children choose to play, how to play, and with whom to play. The child is in control of the play experience, not an adult. If the experience is assigned or chosen for the child, then actual play may not unfold.

Play is not goal-oriented. The process of play is more important to the child than the product of play. A goal is not the object of play, even if a goal is achieved. The absence of a goal frees children to try many different variations of the experience, which is why play tends to be more flexible than goal-oriented behavior. Play provides for multiple possibilities for divergent thinking.

Some types of play are non-literal. The reality the child creates within himself or herself takes precedence over external reality. For example, a block is a block of wood in reality. In play, the child changes reality into what he or she wants the block to stand for. He or she may choose the wooden block to stand for a car, a slice of pizza, or even a space ship.

And, finally, play is enjoyable. Play is self-satisfying, pleasurable, and important to the child. One can observe children playing and can see a range of expression from quiet contentment to exuberant laughter.

Understanding what play is clarifies what types of learning environments should be created and promoted which are inclusive of true play.

\section{Why Play Is So Important for School Contexts}

Why is play so important? Couldn't we just eliminate play from children's lives, particularly their school lives, by replacing recess and classroom play centers and projects with skill and study work? Shouldn't we get on with things society places great importance on, such as working hard, being responsible, following directions, and getting good scores on standardized tests? Surely play in schools could not lead to those goals!

Interestingly, child development experts, theorists, and researchers are in agreement that play is essential in the lives of children and that the absence of play presents a roadblock to the development of healthy, creative individuals (Dickey et al., 2016; Gray, 2011; Isenberg \& Quisenberry, 2002; Sandberg \& Heden, 2011; Wenner, 2009). Even recess is under attack with a call to eliminate it or replace it with teacherdirected physical education. However, we know that recess uniquely provides for the creative, social and emotional development of children (Ramstetter, Murray, \& Garner, 2010). Authors (Elkind, 1982; 
Postman, 1982; Winn, 1981) have written about what they call "the disappearance of childhood." As Wasserman (1992) states, "children today have far fewer opportunities to live in the life of the mind, to be playful, to behave as children" (p. 203). Schooling occurs during a child's most important waking hours of the day, occupying almost $60 \%$ of a child's daily time. Why should play be considered essential for a prized place in the school day?

Consider, for example, why experts explain the importance of play. According to Isenberg and Quisenberry (2002),

psychoanalysts believe that play is necessary for mastering emotional traumas or disturbances; psychosocialists believe it is necessary for ego mastery and learning to live with everyday experiences; constructivists believe it is necessary for cognitive growth; maturationists believe it is necessary for competence building and for socializing functions in all cultures of the world; and neuroscientists believe it is necessary for emotional and physical health, motivation, and love of learning. (p. 33)

Choice and control over their play gives children a sense of autonomy (Masten, 2001). Children, through play, develop a sense of control over their own lives and are less likely to become anxious or depressed (Gray, 2011). Children who are able to express emotion in their play, "feel happier, more energetic, and more cheerful ..." (Fiorelli \& Russ, 2012, p. 100). Play is also key to supporting the development of emotional resiliency in children and gives children a resource for meeting adversity, and for increasing their chances of survival (Fearn, \& Howard, 2012). Play gives children the capacities for self-control, which is crucial to social existence (Gray, 2011; Vygotsky, 1976). Children learn to control their emotions through play, make friends, and learn to get along with others (Gray, 2011). Play contexts afford children the opportunity to feel joy, passion, and creativity as well as to develop their own identity, self-esteem and sense of self (Sandberg \& Heden, 2011).

Gray (2011) states:

Somehow, as a society, we have come to the conclusion that to protect children from danger and to educate them, we must deprive them of the very activity that makes them happiest and place them for ever more hours in settings where they are more or less continually directed and evaluated by adults, settings almost designed to produce anxiety and depression. If we wish children to be happy and to grow up to become socially and emotionally fulfilled and competent adults, we must provide them, once again with opportunities to spend many hours per day playing freely with friends. (p. 458)

If we want to support the healthy development of a child, to nurture their well-being, then play is essential! Play ensures children's well-being and development (Russell \& Lester, 2009). If we want children to grow up to be psychologically healthy and competent adults, the best gift, and essential gift, we can give our children is free play. 


\section{Play in School Contexts}

Recently, an early childhood teacher said, "I don't have a dramatic play area in my classroom because the children are too noisy, but I don't know what to do with the children because they are crawling on the floor pretending to be cats! Can someone help me?" Unfortunately, the teacher was equating a quiet, controlled classroom to one in which children are "learning" in the traditional sense, not realizing she had built a barrier to children's "real" learning. For example, research demonstrates that a dramatic play area supports children using more elaborate language (Pellegrini, 1984; Reynolds, Stagnitti, \& Kidd, 2011), greater story comprehension (Christie, 1987), and story recall (Silvern, Taylor, Williamson, Surbeck, \& Kelley, 1986). In addition, this type of play gives opportunities for children to develop friendships, express their feelings, and also learn about negotiating, resolving conflicts, fairness and competition (Stone, 1993).

For some reason educators have equated "learning" to goal-oriented worksheets, which lead the children through a sequence of curriculum in a linear fashion. Playing, then, is not "real" learning because it is outside the framework of the sequenced, standardized curriculum. Teachers often feel compelled or required to cover that curriculum in order to "teach" the children the prescribed curriculum. In this sense, some schooling models have chosen a curriculum-centered approach to learning, instead of a childcentered approach.

Dewey (1938), the originator of the term "child-centered," was concerned with the overall well-being of children. He wanted educators to consider children in the process of educating them. He could see that a uniform curriculum was not a good fit for children and their needs. Play, on the other hand, is a natural learning opportunity for children, which also protects, supports, and nurtures their well-being. The following are actual play examples, which demonstrate the deep learning that takes place through play, which you cannot teach with a worksheet or a curriculum-centered approach.

Negotiation. Two children, ages five and six, entered the home center at almost the same time. The first child announced, "I'm the mom!" The second child said, "No, I'm the mom!" The first child said, "I'm the mom. I was here first." The second child pleaded with a very sad face, "But, I want to be the mom." The first child, recognizing her dismay, responded, "OK, I'Il be the mom first and you can be the mom second." You can't teach that with a worksheet!

Cognitive Planning. A group of five-, six-, and seven-year-olds arranged chairs in the mixed-age classroom and then sat in the chairs, motioning that they were driving someplace. The teacher watched as the children organized the chairs in rows, had given roles to each other, and were obviously playing out a story. The teacher's curiosity led her to ask the children what they were doing. They responded that they were all in a motor home on their way to Las Vegas for two of the children to get married. Apparently, one of the children experienced this real-life event with her family. The mental organization of the story was played out meticulously. You can't teach that with a worksheet!

Problem-solving. A five-year-old was involved in constructive play at the art center. She was building a tower with wooden blocks and gluing them together. She discovered that the glue was slippery and the 
blocks were sliding out from one another. This was a problem for her. She looked over to another table and saw a tape dispenser. As quickly as she could, she left her project, got the tape, and secured her tower. Then she applied tape all over the tower to keep the blocks together while the glue dried. She solved the problem. You can't teach that with a worksheet!

Imagination. A five-year-old was playing with other children at the home center. As they played "school," the center table was covered with several pencils and paper. As the other children left, the five-year-old sat alone and began to put the pencils in between his fingers. He then put the pencils down, left the center, and returned quickly with more pencils, again, putting them between his fingers. Slowly and quietly, the child motioned with his hands and pencils the claws he created and transformed himself into the character, Wolverine. What a remarkable transformation of imagination. You can't teach that with a worksheet!

Friendship. Two three-year-olds were playing together in their preschool. One child had decided to decorate himself with colored strips of paper. The other child saw what he was doing and decided to help him accomplish this project. Carefully, he provided strips of paper and tape to put on his playmate. After some time, the decorated child asked his playmate, "Why are you doing this for me?" The child responded, "Because you are my friend, silly!" You can't teach that with a worksheet!

We know that when children play together, they are free to "define goals, plan, solve problems, negotiate and coordinate their behavior" (Ramani, 2012, p. 163) to sustain their play and reach shared goals. Play provides an arena of learning for the whole child: cognitive, social, emotional, and physical well-being (Dickey et al., 2016; Stone, 1995). Nancy Carlsson-Paige describes play as "an engine driving children to build ideas, learn skills and develop capacities they need in life . . . In play children develop problem solving skills, social and emotional awareness, self-regulation, imagination and inner resilience" (Ravitch, 2016). Play is child-driven, sophisticated, complex, dynamic, flexible, and personal, all within a context that is rewarding, safe, and full of possibilities. Play is foundational to a child-centered approach to learning.

\section{Curriculum- or Child-Centered Approach to Learning}

A curriculum-centered approach takes a narrow band of input into learning. This approach tries to "fit children to a set curriculum," rather than "fitting the curriculum" to children's needs. Unfortunately, when schooling is centered on the curriculum and not on the child, it does not fit the exact place a child is building his or her knowledge and understanding.

In play, the child is learning at exactly his or her point of understanding. A problem presented by a teacher may not be where the child is, but a problem presented in play is only a problem if the child sees it as so. Play is that perfect fit for the child and his or her understanding.

Social play is a natural scaffold for children to decenter and to make friends. It is the natural tool for cognitive dissonance where one child has a different point of view than another child, leading the children to reconsider what they know and understand, often leading them to deeper understanding. 
Play, as Selma Wasserman (1992) suggests, "allows children to make discoveries that go far beyond the realm of what we adults think is important to know" (p. 202). Do we choose a narrow curriculumcentered or a broad child-centered approach to education that allows children to make discoveries that are important and personally relevant to them?

Not providing play opportunities for children in the school context, runs the risk of creating "dot-to-dot" children-children, who master paint-by-number skills, instead of painting a masterpiece of their own imagination and creation.

Brain research suggests that play supports an active brain, and an active brain "makes permanent neurological connections critical to learning; inactive brains do not make the necessary permanent neurological connections" (Isenberg \& Quisenberry, 2002, p. 33). Play increases neural structures and scaffolds development. The parts of the brain that children use when playing are integrated mainly in the connections between the amygdala (predominantly emotional center) and neocortex (predominantly thinking center) according to Fromberg (2002). She notes that

the same parts of the brain also affect attention, potential attitudes toward learning, creative thinking, problem solving, and the arts. Strengthening the amygdala strengthens these interrelated capacities ... When children perceive that events are personally relevant to them, their neural connections proliferate and situations and ideas become part of their long-term memory. Meaningless things ... . will not typically become part of long-term memory. (pp. 29-31)

Stone (1992) found that when children "played" with Greek letters within a story context, the letters became part of their long-term memory. However, when a traditional approach of learning letters was used (chanting, repeatedly writing letters, skill and drill), children did not retain the letters in long-term memory. Play within a story provided a meaningful context for the children.

Play is the optimal context for meaning to develop. Meaning is when one understands something; it makes sense. Children make sense of their world through play. Meaning includes concepts, ideas, emotions, and motives - the whole of life. Children's affect-how they feel-is also important to their learning because when children are busy worrying about their competence or coping with a sense of inadequacy, they find it difficult to focus on new meanings (Fromberg, 2002; Bruner, 1983). When a curriculum-centered approach is out of sync with a child's understanding, it dangerously risks the child's ability to learn, creating stress for the child, rather than well-being (Elkind, 1982).

A curriculum-centered approach to learning is often called a linear curriculum (Fromberg, 2002). However, children learn in nonlinear ways. Every child is unique in how he or she learns and how long it takes to build individual understanding. A linear curriculum is also more likely to initiate a sense of inadequacy or failure, whereas there is no failure in play. Play is nonlinear and in the control of the child. With school failure, children are at high risk of retention, a side effect of a curriculum-centered school model. Research demonstrates that retention is anti-well-being. Children who do not fit the rigid benchmarks of grade-level standards and are subsequently retained, equate retention with the stress of a death in the family (Shepard \& Smith, 1986). A linear curriculum encourages a one-size-fits-all approach to learning. Whereas, a child-centered approach, incorporating play, supports the affective side of 
learning. "Positive emotions such as curiosity, generally improve motivation and facilitate learning. .. ; negative emotions, such as anxiety, panic, threats, and stress, generally detract from motivation (Isenberg \& Quisenberry, 2002, p. 36). For example, a fourth-grade teacher noted how one of her students came to her in tears because he felt threatened by the high-stakes test, which would occur the next day. She tried her best to console the child, but could not relieve the child of his anxiety and stress over the fear of failure and ultimate retention. The impact of stressful, high-stakes tests in a curriculum-centered approach encroaches on child abuse in the arena of caring for the well-being of children. Should schooling be about threatening children for the sake of a test score?

In a linear environment, curriculum-centered approach, one will also find children who are passive, submissive, "afraid to take risks or rise to the challenge, who shy away from new problems, content that once the answer has been found, there's no need to learn any further" (Wasserman, 1992, p. 122). A linear environment usually is a classroom, which is task oriented, where the learning is directed by the teacher so children are not "off task." In a nonlinear environment, children have the freedom to play with ideas, socialize with others, and become autonomous learners. Children also enjoy the freedom of time to build their own understandings. Play contributes to a "child's sense of success, power, and self-esteem" (Fromberg, 2002).

\section{The Importance of Play and Imagination}

Some types of schooling value rational, linear processes more than imaginative, nonlinear processes. Following the dotted line of the curriculum becomes more important than creating a brushstroke of color, original design, and personal flair. Vygotsky (1976) suggests that play leads development, and imagination is a future-oriented phenomenon. Imagination lets us invent things that are not yet reality. Theorists (Fein, 1987; Singer \& Singer, 1990) also consider imaginative play as crucial to children's mental health and social adjustment.

In Selma Wasserman's article (1992), Serious Play in the Classroom, she notes how many eminent adults departed from normal schooling in order to "play around." For example, the Wright brothers asked their mother if they could stay home from school so they could "tinker around in the backyard." Their mother said, "yes," and they invented the airplane. Frank Lloyd Wright, the famed, innovative architect, was encouraged by his mother to play with "colored papers and cubes of wood" (p. 203). She believed this type of play would enhance his intellectual development. In play, children are not locked into conforming to a set of standards of what is right or wrong. As Wasserman notes, "The creation of new ideas does not come from minds trained to follow doggedly what is already known. Creation comes from tinkering and playing around, from which new forms emerge" (p. 203). Shakespeare surely would not have pleased his teacher because he played with language and invented the words like majestic, hurry, lonely, and radiance instead of using traditional, established words.

Richard Feynman, Nobel Prize winner in Physics, relates in his book, Surely You're Joking Mr. Feynman (1985), how play contributed to his love of physics and his winning of the Nobel Prize. He worked out an equation for wobbles by simply playing. The Wright brothers, Frank Lloyd Wright, Shakespeare, and 
Feynman are just a few examples of the relationship of play to creative adulthood. Wasserman (1992) notes, "The freedom to create and invent appears to be closely connected with the development of creative, inventive, innovative adults" (p. 203).

\section{Advocating for a Place in School}

Powerful learning emerges from play and surely should not be separated from play (Frost, Wortham, \& Reifel, 2008). Pressure to learn skills outside of the play context can be stressful for children, which does not support their well-being; it is "mis-educating" children (Elkind, 1987, 1990; Little \& Cohen-Vogel, 2016). The best schools are places that support "warm human relationships, imaginative play, and playful learning and children participate in choosing their activities . . . not following rigid curricula designed to increase test scores" (Miller \& Almon, 2011, p. 17).

However, the current, dominant view of education is not focused on the well-being of children. A standards-driven education with a highly prescriptive curricula and high-stakes tests deprives children of the "pleasure and personal value of learning, discover, and coming to be" (Thomas, 2010, p. 33). As Miller and Almon (2011) note, "The desire for a fast track to success, coupled with the push for tough standards and test-based accountability, has built a new superhighway without speed limits or guardrails-a dangerous place for children" (pp. 2-3). As a parent, Tama Koss Caldarone (2016) describes how her young daughter loves to create and play, but at school, she is "herded like cattle, not treated like a child. She is forced to sit in a chair most of her day watching a screen" which her teacher uses to teach "through a computer projected onto a wall (p. 1)." She believes our children deserve better.

We must not deny our children the essentials for a healthy life. We must contribute to their well-being!

Nancy Carlsson-Paige (2013) in her TedTalk, "When Education Goes Wrong: Taking the Creativity and Play out of Learning," passionately states:

When we watch children play, we understand how central play is to healthy development - to children's emotional, social, and cognitive health and learning. Through play . . . children build ideas and relationships that become the foundation for success . . Today's overemphasis in schools ... on standards and testing is ... resulting in more and more direct instruction at the expense of play ... When we drill and grill children, we cut out the powerful natural capacities they bring to the learning experience - their creativity, original thinking, capacity to problem solve and invent new ideas, their natural ability to cooperate, initiate, and persevere. When we take these amazing capabilities children have out of the education experience, we take out the love of learning. What we have to do is figure out: How do we create an educational system. . . that nurtures and develops and builds onto the magnificent capacities children bring with them when they come to school?

Do we want to produce dot-to-dot children who fill in the blanks, or do we want our children to think for themselves, to create and invent, and to love learning? Engel (2015) asks us to consider that, "if we want to create happy children who love learning, forcing them to sit at desks or tables through early childhood is not going to do it. They need to play ..." (p. 324). 
If play is absent from schooling or minimized because of perceived "more important" learning, we significantly decrease the possibilities for children to build meaning and understanding, imagine, and create. We crowd out important types of learning with an increasing focus on academics and an absence of play (Bassok, Latham, \& Rorem, 2016; Levin, 2016; Strauss, 2016).

Carlsson-Paige adds:

There are also impressive numbers of young children who do manage to adapt to overly academic programs. But even for them, it comes at a cost. They lose out on all the benefits of play-based learning. Instead they learn facts and skills by rote practice; they learn that there are right and wrong answers, that the teacher defines what is learned. They learn compliance. They don't get to discover that they can invent new ideas. They don't get to feel the sense of empowerment found in playful learning (Strauss, 2016).

Haji and Cuypers (2011) invite us to consider that the aim of education should include the "intrinsic value of personal well-being" where each child's life is personally good as well as good for others. In addition, Elkind (1989) sees the aim of education as facilitating development, creative activity, and the personal construction of knowledge which is accommodated in practices that are appropriate for children, including play, rather than producing children who score high on tests of achievement through the use of inappropriate practices. Elkind advocates replacing psychometric educational psychology, which sees the learner's abilities only measured by tests, with a developmentally appropriate approach that sees the learner as developing abilities through personal construction. The two philosophies are in total opposition according to Elkind. Which one do we choose? Which one provides a learning environment, including play, where children can thrive and flourish? Brighouse (2006) believes the aim of education is to "promote human flourishing" and the "school should see itself as having an obligation to facilitate the long-term flourishing of the children" (p. 42).

Without play, what a colorless place the world will be for our children! More importantly, we cannot sacrifice the well-being of children on the altar of a curriculum-centered, standards-based approach, and accompanying high-stakes tests. We cannot trade the freedom and power of play for the pressure of rigid schooling and testing. We cannot abandon our children's well-being, quality of life, now nor in the future. We must find a way to invent and support a schooling system which is nonlinear, child-centered, and incorporates play as a process to learning. We must invent a schooling system that supports and nurtures the well-being of every child. 


\section{References}

Almon, J. (2013). It's play time. Principal. September/October, 13-15.

Bassok, D., Latham, S., \& Rorem, A. (2016). Is kindergarten the new first grade? AERA Open, 1(4), 1-31.

Brighouse, H. (2006). On education. London: Routledge.

Bruner, J. (1983). Play, thought, and language. Peabody Journal of Education, 60(3) 60-69.

Burriss, K., \& Tsao, L. (2002). How much do we know about the importance of play in child development? Childhood Education, 78(4), 230-233.

Caldarone, T. (2016). My first grader doesn't like school - and I don't blame her! Dey Project. Retrieved from http://www.deyproject.org/guest-blog/coming-soon-guest-bloggers-from-across-the-country.

Carlsson-Paige, N. (2008). Reclaiming play: Helping children learn and thrive in school. Exchange: The Early Childhood Leaders/Magazine Since 1978. 180, 44-48.

Carlsson-Paige, N. (2013). When education goes wrong: Taking creativity and play out of learning. TEDxTheCalhounSchool. Retrieved from https://www.youtube.com/watch?v=BZzFM1MHz_M.

Chmelynski, C. (2006). Play teaches what testing can't touch: Humanity. Education Digest, 72(3), 1013.

Christie, J. F. (1987). Play and story comprehension: A critique of recent training research. Journal of Research and Development, 21(1), 36-42.

Copple, C., \& Bredekamp, S. (2009). Developmentally appropriate practice in early childhood serving children from birth to age 8 . Third edition. Washington, DC: NAEYC.

Dewey, J. (1938). Experience in education. New York: Collier.

Dickey, K., Castle, K., \& Pryor, K. (2016). Reclaiming play in schools. Childhood Education, 92(2), $111-$ 117.

Dowdell, K., Gray, T., \& Malone, K. (2011). Nature and its influence on children's outdoor play. Australian Journal of Outdoor Play, 15(2), 24-35.

Elkind, D. (1982). The hurried child. Boston: Allyn \& Bacon.

Elkind, D. (1987). Miseducation: Preschoolers at risk. New York: Knopf.

Elkind, D. (1989). Developmentally appropriate practice: Philosophical and practical implications. Phi Delta Kappan, 71(2), 113-117.

Elkind, D. (1990). Academic pressure - too much, too soon. The demise of play. In E. Klugman \& S. Smilansky (Eds.), Children's play and learning: Perspectives and policy implications (pp. 3-17). New York: Teachers College Press.

Elkind, D. (2007). The power of play. Cambridge, MA: Da Capo Lifelong Books.

Engel, M. (2015). The importance of free play in the early childhood classroom: Perspectives from a teacher. Childhood Education, 91(5), 323-324. 
Fein, G. (1987). Pretend play: Creativity and consciousness. In P. Gorlitz \& J. Wohlwill (Eds.), Curiosity, imagination, and play (pp. 281-304). Hillsdale, NJ: Erlbaum.

Fern, M., \& Howard, J. (2012). Play as a resource for children facing adversity: An exploration of indicative case studies. Children \& Society, 26, 456-468.

Feynman, R. (1985). Surely you're joking Mr. Feynman. New York: Norton.

Fiorelli, J., \& Russ, S. (2012). Pretend play, coping, and subjective well-being in children. American Journal of Play, 5(1), 81-103.

Fromberg, D. (2002). Play and meaning in early childhood education. Boston: Allyn \& Bacon.

Frost, J. (1992). Play and playscapes. Albany, NY: Delmar.

Frost, J., Wortham, S., \& Reifel, S. (2008). Play and child development. Upper Saddle River, NJ: Pearson/Merrill Prentice Hall.

Graue, E. (2010). Reimagining kindergarten. Education Digest, 75(7), 28-34.

Gray, P. (2011). The decline of play and the rise of psychopathology in children and adolescents. American Journal of Play, 3(4), 443-463.

Haji, I., \& Cuypers, S. E. (2011). Ultimate educational aims, overridingness, and personal well-being. Studies in Philosophy and Education, 30(6), 543-566.

Humberstone, B. (2009). Well-being and outdoor pedagogies in primary school: The nexus of well-being and safety. Australian Journal of Outdoor Education, 13(2), 24-32.

Isenberg, J., \& Quisenberry, N. (2002). Play: Essential for all children. Childhood Education, 79(1), 3339.

Jachyra, P., \& Fusco, C. (2016). The place of play: From playground to policy to classroom well-being. Education \& Society, 21(2), 217-238.

Johnson, J. E., Christie, J. F., \& Wardle, F. (2005). Play, development, and early education. Boston: Pearson/Allyn \& Bacon.

Levin, D. (2012). Changing times, changing play: Why does it matter? Exchange, September/October.

Levin, D. (2016). What has happened to play? Community Play Things. Retrieved from http://www.communityplaythings.com/resources/articles/2016/endangered-play.

Little, M., \& Cohen-Vogel, L. (2016). Too much too soon? An analysis of the discourses used by policy advocates in the debate over kindergarten. Education Policy Analysis Archives, 24(106), 1-35.

Masten, A. (2001). Ordinary magic. Resilience processes in development. American Psychologist, 56(3), $227-238$.

Miller, E., \& Almon, J. (2009). Crisis in kindergarten: Why children need to play in school. Alliance for Childhood, March, 1-8. 
Miller, E., \& Almon, J. (2011). Crisis in the kindergarten: Why children need to play in school. College Park, MD: Alliance for Childhood.

Neason, A. (2015). Welcome to kindergarten. Take this test. And this one. Slate. Retrieved from http://www.slate.com/blogs/schooled/2015/03/04/kingergarten_has_changed_less_time_for_play_more _time_for_standardized_tests.html

Pellegrini, A.D. (1984). The effects of exploration and play on young children's associative fluency: A review and extension of training studies. In T. D. Yawkey \& A. D. Pellegrini (Eds.), Child's play: Developmental and applied (pp. 237-253). Hillsdale, NJ: Erlbaum.

Postman, N. (1982). The disappearance of childhood. New York: Delacorte.

Ramani, G. (2012). Influence of a playful, child-directed context on preschool children's peer cooperation. Merrill-Palmer Quarterly, 58(2), 159-190.

Ramstetter, C., Murray, R., \& Garner, A. (2010). The crucial role of recess in schools. Journal of School Health, 80(11), 517-526.

Ravitch, D. (2010). The death and life of the great American school system: How testing and choice are undermining education. New York: Basic Books.

Ravitch, D. (2016). Nancy Carlsson-Paige: The error of killing play in kindergarten. Retrieved from https://dianeravitch.net/2016/08/24/nancy-carlsson-paige-the-error-of-killing-play-in-kindergarten/

Reynolds, E., Stagnitti, K., \& Kidd, E. (2011). Play, language and social skills of children attending a playbased curriculum school and a traditionally structured classroom curriculum school in low socioeconomic areas. Australasian Journal of Early Childhood, 36(4), 120-130.

Russell, W., \& Lester, S. (2009). Children's Right to Play: An Examination of the Importance of Play in the Lives of Children Worldwide. Summary Paper. International Play Association.

Sandberg, A., \& Heden, R. (2011). Play's importance in school, Education 3-13, International Journal of Primary, Elementary and Early Years Education, 39(3), 317-329.

Shepard, L. A., \& Smith. M. L. (1986). Synthesis of research readiness and kindergarten retention. Educational Leadership, 44(3), 78-86.

Silvern, S. B., Taylor, J. B., Williamson, P. A., Surbeck, E., \& Kelley, M. F. (1986). Young children's story recall as a product of play, story familiarity, and adult intervention. Merrill-Palmer Quarterly, 32(1), 7386.

Singer, D., \& Singer, J. (1990). The house of make-believe: Children's play and developing imagination. Cambridge, MA: Harvard University Press.

Stone, S. J. (1992). Dissertation: Effects of emotionally laden stories with play on recognition, reconstruction and recall memory for letters. Tempe, AZ: Arizona State University.

Stone, S. J. (1993). Playing: A kid's curriculum. Glenview, IL: GoodYear Books.

Stone, S. J. (1995). Wanted: Advocates for play in the primary grades. Young Children, 50(6), 45-54.

Stone, S. J. (2004). Creating the multiage classroom. Culver City, CA: GoodYear Books. 
Strauss, V. (2016). Our misguided effort to close the achievement gap is creating a new inequality: The 'play' gap. The Washington Post. Retrieved from https://www.washingtonpost.come/news/answersheet/wp/2016/08/23/o...-gap/?postshare=21471983687726\&tid=ss_fb\&utm_term=.7aa62c0bc96d

Thomas, P. L. (2010). Why common standards won't work. Education Week, 29(37), 33.

Vygotsky, L. S. (1976). Play and is role in the mental development of the child. In J. S. Bruner, A. Jolly, \& K. Sylva (Eds.), Play: Its role in development and evolution (pp. 537-544). New York: Basic Books.

Wasserman, S. (1992). Serious play in the classroom. Childhood Education, 68(3), 133-139.

Wenner, M. (2009). The serious need for play. Scientific American Mind, February/March, 22-29.

Winn, M. (1981). Children without childhood. New York: Pantheon.

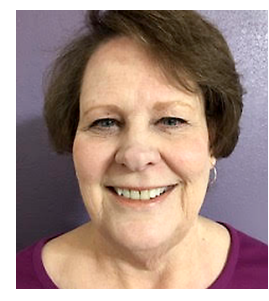

Sandra J. Stone, PhD, an author and speaker, is Professor Emerita at Northern Arizona University. Dr. Stone's publications and research focus on multiage education, play, and literacy. She has worked extensively with schools and teachers internationally, particularly with multiage education. She is the past editor for the Journal of Research in Childhood Education and for several columns in the journal Childhood Education. She serves on editorial boards for several international research journals. 